\title{
Electron Microscopical and Immunohistochemical Study on Parafollicular Cell Complex with Reference to Parafollicular Cell as a Paraneuron
}

\author{
Yoko KAMEDA
}

\begin{abstract}
Summary. In mammalian species, parafollicular cells were usually disseminated among the follicles of the thyroid gland; but they occasionally formed fairly large clusters around the parathyroid IV and thymus IV. These cell clusters were called parafollicular cell complexes and were regarded as the remnant of the embryonic ultimobranchial body. The parafollicular cell complex contained follicular cells in addition to parafollicular cells. Colloid-containing follicles also occurred. In order to assess the developmental and functional relationship between follicular cells and parafollicular cells, the parafollicular cell complex in the dog was investigated by means of immunohistochemical method and electron microscopy.

Follicular cells in the parafollicular cell complex showed various ultrastructures representing every developmental stage. The cells forming solid clusters without follicles were indistinguishable from the precursor cells of the parafollicular cells. Parafollicular cells occasionally formed narrow colloid-containing follicles.

The results of the immunoperoxidase study indicated that the follicular cells in the parafollicular cell complex elaborated 19s thyroglobulin and stored it as colloid droplets in the follicular lumen. The antigenicity of the colloid droplets in the parafollicular cell complex was much stronger than that of the thyroid follicles.

Based on these results, the origin of the parafollicular cells was discussed with special reference to the paraneuron concept of FUJITA (1976). The theory that both follicular and parafollicular cells were of endodermal origin seemed valid.
\end{abstract}

The parafollicular cells (C cells) of the thyroid gland have been regarded as a member of the paraneurons (FujITA, 1976). They synthesize and secrete calcitonin, a serum calcium-lowering polypeptide hormone. They have the potency of taking up amine precursors and decarboxylating them, as listed in the APUD series of PEARSE (1969). The fine structure of the parafollicular cells is typical of paraneurons. Thus, the cytoplasm having a clear matrix is filled with numerous secretory granules. Although parafollicular cells of mammals, which are scattered in the thyroid tissue, have no direct contacts with nerve endings, those in lower vertebrate species including birds, where the parafollicular cells occur in the ultimobranchial body, have rich innervation (W Atzka, 1933; Robertson, 1967; Stoeckel and Porte, 1969; Welsch and Schubert, 1975). Thus, the parafollicular cell satisfies most of the criteria for being listed as a paraneuron; the only exception concerns its origin.

If the parafollicular cell is a paraneuron, it is essential that it originates from the neuroectoderm as proposed by FuJITA (1976). With this point in mind, the parafollicular cell complex (KAMEDA, 1971a, 1973, 1974, 1976) has recently been investigated using electron microscopy and immunohistochemistry. In the parafollicular cell complex, colloid-containing follicles lined by ordinary follicular cells are frequently seen (KAMEDA, 1971a, 1973, 1974, 1976). Therefore, this organ was selected for investigating the cytological similarities and differences between the parafollicular 
cells and the follicular cells.

\section{Some cytological features of the parafollicular and follicular cells}

The follicular cells synthesize thyroid hormones such as triiodothyronine and thyroxin. Thyroglobulin, a protein precursor of the thyroid hormones, is also produced by the follicular cells. On the other hand, the parafollicular cells synthesize and secrete calcitonin. They are specifically sensitive to changes in the concentration of serum calcium. During chronic hypercalcemia the parafollicular cells of dogs become conspicuously enlarged and undergo marked degranulation; furthermore, the mitotic activity increases resulting in a conspicuous proliferation of the cells (KAMEDA, 1970). Remarkable degranulation and increase in the amount and size of rough endoplasmic reticulum and Golgi complex are induced after hypercalcemia, while hypocalcemia induces an accumulation of dense, large secretory granules (KAMEDA, 1973). In contrast to the parafollicular cells, the follicular cells are not affected by hypercalcemia or hypocalcemia.

Blood capillaries surrounding follicles and parafollicular cells form a continuous network. This was recently confirmed by scanning electron microscopy of the vascular casts prepared by using methylmethacrylate (Fig. 1).

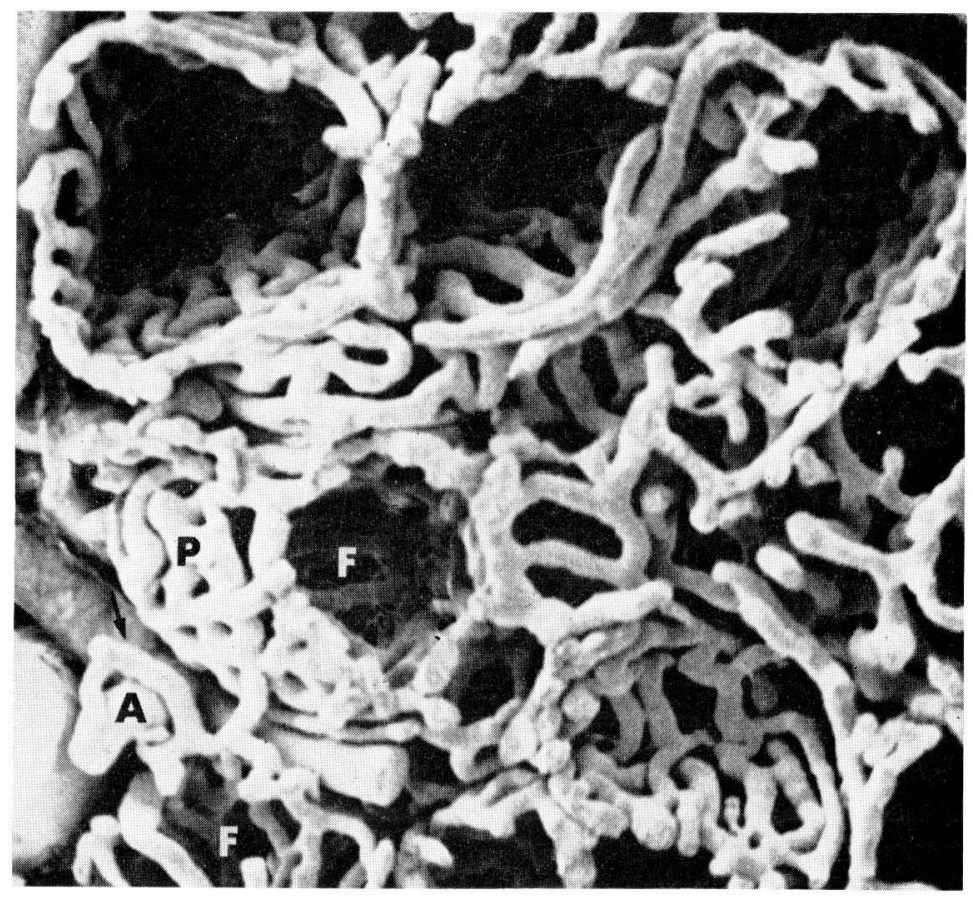

Fig. 1. Vascular cast of the dog thyroid gland seen under scanning electron microscope. Blood capillaries encapsulating a follicle constitute a round or oval basket-like structure, while those of parafollicular cell group constitute a check-like network. A branch (arrow) derived from a interfollicular artery $(A)$ makes complex network supplying both parafollicular cell groups $(P)$ and follicles $(F) . \quad \times 240$ 
It has been reported that in the area surrounding large groups of parafollicular cells the thyroid follicles are always small. The follicular epithelium here looks more active than those in the regions with a few parafollicular cells. CARE (1968) reported the synergistic effect of thyroid hormones to calcitonin. He demonstrated that the administration of thyroid hormones enhanced the hypocalcemic response to injected calcitonin. This arrangement of the blood capillaries in the thyroid gland may facilitate the interaction between parafollicular and follicular cells.

After repeated injections of the anti-thyroid drug, not only follicular cells but also parafollicular cells appear to show hyperactive and hypertrophic features; i.e. enlarged cell bodies, vacuolated rough endoplasmic reticulum and swollen Golgi complex (KAMEDA, 1974). Thus, it appears that the anti-thyroid drug inhibits not only the synthesis of thyroglobulin in the follicular cells but also the activity of the parafollicular cells.

\section{Parafollicular cell complex}

The ultimobranchial body of mammalian species is incorporated within the thyroid gland in early embryonic development and gives origin to parafollicular cells which in the adult are dispersed between the thyroid follicles. In the rabbit, cat, dog and goat, the parafollicular cells are concentrated around the parathyroid IV and thymus IV (both of which bud from the area adjacent to the ultimobranchial body in early fetal life; KAMEDA, 1971b). The parafollicular cells are also seen within the parathyroid IV of rabbits, goats and cats and within the thymus IV of dogs and cats (KAMEDA, 1971b).

In dogs and cats, there occurs a special structure, designated by the author as the parafollicular cell complex, which consists of masses of parafollicular cells and other epithelial elements (KAMEDA, 1971a). Here, peculiar embryonic cells are frequently encountered. These small undifferentiated cells are characterized by a dark cytoplasm, chromatin-dense nucleus and poorly developed cell organelles. Every intergradation from these cells to the mature parafollicular cells with many secretory granules is observed. All these cells undergo hypertrophy during hypercalcemia (KAMEDA, 1973, 1976).

Large parafollicular cell groups dispersed in the thyroid parenchyme show characteristics similar to those of the parafollicular cell complexes. These groups of cells contain immature parafollicular cells, undifferentiated epithelial cells and interstitial cells, and may represent the parafollicular cell complex in the thyroid gland.

\section{Recent electron microscopic study on the colloid-containing follicles within the parafollicular cell complex}

Normal dogs of various ages and of either sex were used. The thyroid gland together with surrounding tissue was perfused from the common carotid artery for 15 to 30 min with buffered glutaraldehyde, were excised and fixed for an additional $2 \mathrm{hrs}$ in glutaraldehyde. They were then postfixed with osmium tetroxide. The specimens were embedded in Epon by the standard method. Thin sections made with glass knives were doubly stained with uranyl acetate and lead citrate, and then observed in the electron microscope.

The parafollicular cell complex retained the characteristics of the fetal ultimobranchial body (KAMEDA, 1973, 1976). The small peculiar embryonic type para- 


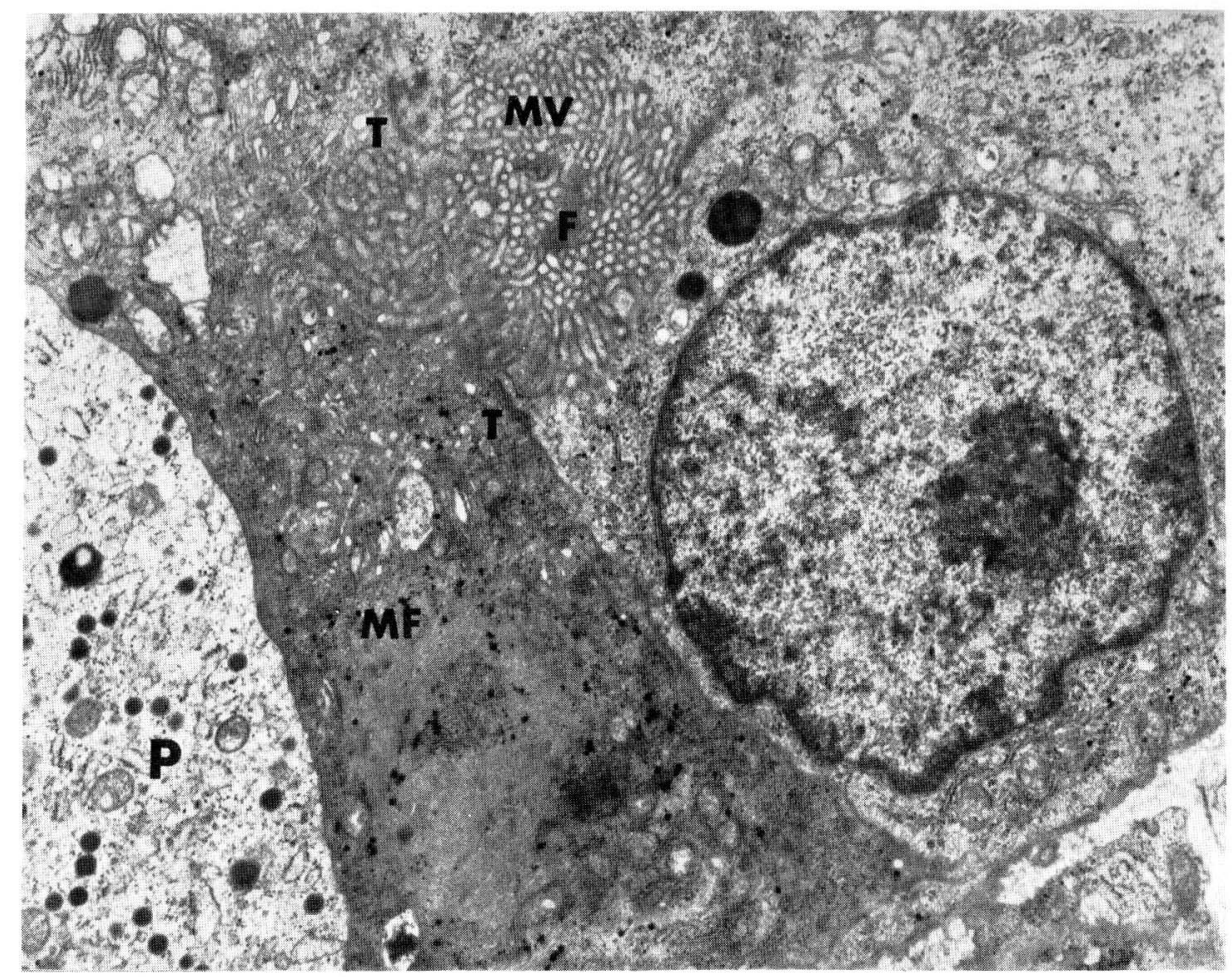

Fig. 2. Microfollicle $(F)$ in the parafollicular cell complex covered with undifferentiated cells. Cell containing bundles of microfilaments $(M F)$ in the dark cytoplasm. $P$ parafollicular cell, $M V$ microvilli, $T$ tight junction. $\quad \times 11,500$

follicular cells were characterized by dark cytoplasm, chromatin-dense nucleus and poorly developed cell organelles. They were identified as parafollicular cells by the presence of membrane-bound secretory granules, though small in number. Every transitional form between these cells and the mature parafollicular cells with many secretory granules was seen.

The parafollicular cell complex possessed colloid-containing follicles of various sizes. For convenience of description, follicles in the complex were classified into large follicles, minute follicles and microfollicles based on size. The ultrastructural features of large follicles were identical with those of the ordinary thyroid follicles. The cells lining the large follicle were indistinguishable from the mature follicular cells of the thyroid gland. Minute follicles and microfollicles were surrounded by immature-looking follicular cells having poorly developed endoplasmic reticulum. In general, the smaller the follicles the less mature-looking was the lining cells.

Occasionally, the parafollicular cells formed a follicular structure (Fig. 5). Here no mingling of undifferentiated cells or follicular cells was observed. A few microvilli (or just cytoplasmic processes) protruded into the lumen at the apical surface of the parafollicular cells. The luminal colloid of the follicles lined solely by the parafollicular cells appeared identical to that of the thyroid follicles.

In the parafollicular cell complexes, there were a few non-granulated epithelial 

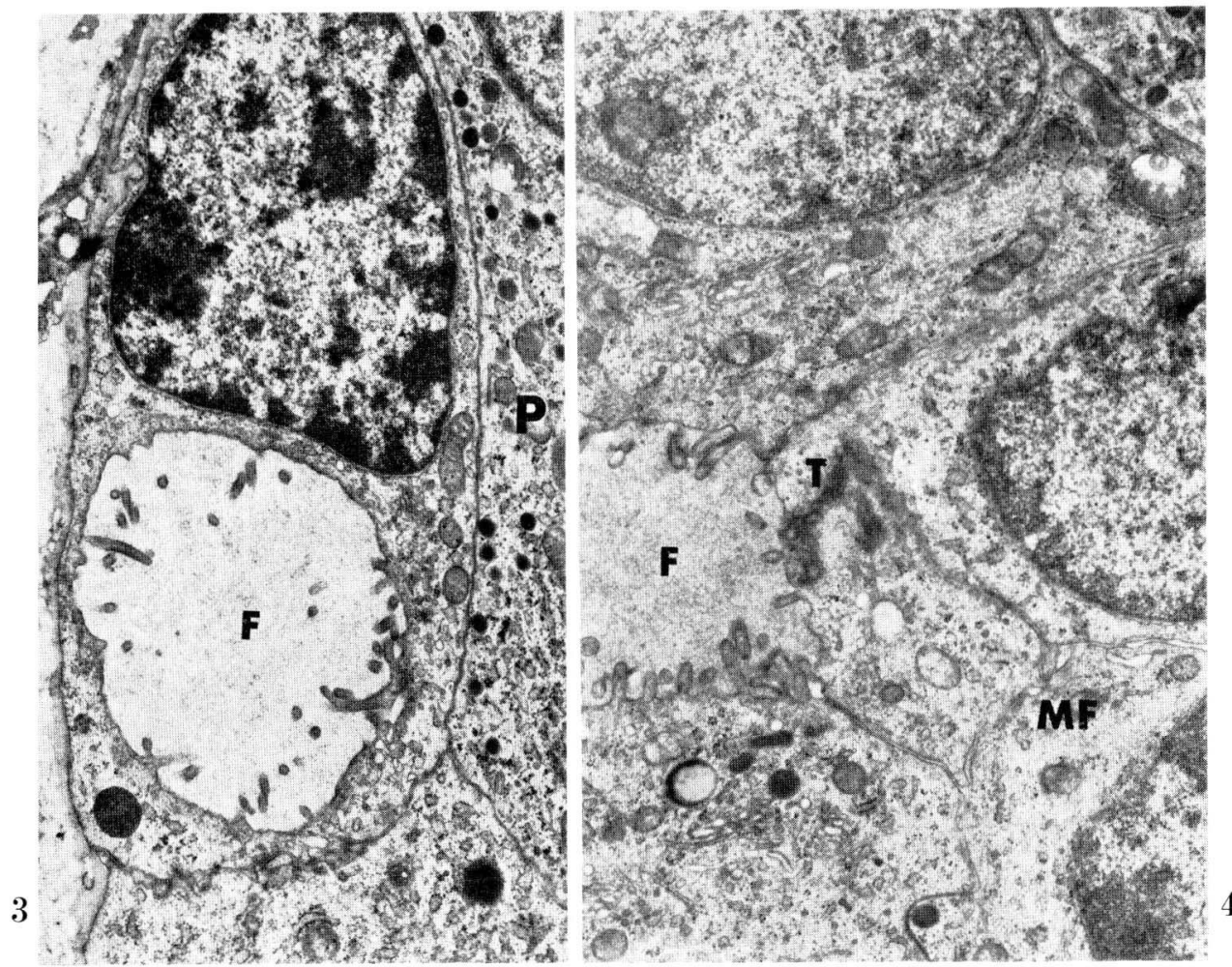

Fig. 3. Intracytoplasmic follicle $(F)$ containing colloids of moderate density. $P$ parafollicular cell. $\times 11,500$

Fig. 4. Microfollicle $(F)$ in the parafollicular cell complex. Cells lining the follicle resemble the follicular cells in the thyroid gland. They contain accumulations of microfilaments $(M F)$ and profiles of rough endoplasmic reticulum. $T$ tight junction. $\times 13,800$

cells characterized by a small, dark cytoplasm and chromatin-rich nucleus. These cells were regarded as undifferentiated cells (KAMEDA, 1973, 1976). It was noticed that the undifferentiated cells also formed narrow follicular structures (Fig. 2, 3). Some undifferentiated cells contained bundles of microfilaments throughout the cytoplasm. Numerous long microvilli were seen at the apical cell surface which was sealed by the junctional complex. Colloid droplets of variable density filled the lumen. Occasionally, empty follicles or those filled with a foamy substance were seen. Every transitional form between the undifferentiated cell and follicular cell was encountered (Fig. 4).

\section{Immunohistochemical study of the parafollicular cell complex using anti-19s thyroglobulin antiserum}

Antibodies specific to $19 \mathrm{~s}$ thyroglobulin were prepared in our laboratory (for details, see Kameda and Ikeda, 1977b). By gel filtration on Bio-Gel A-5m (6\% agarose gel) column, I to IV peak fractions were obtained from partially purified dog thyroglobulin. The peak I contained faster sedimentation components such as $27 \mathrm{~s}, 37 \mathrm{~s}$ and 


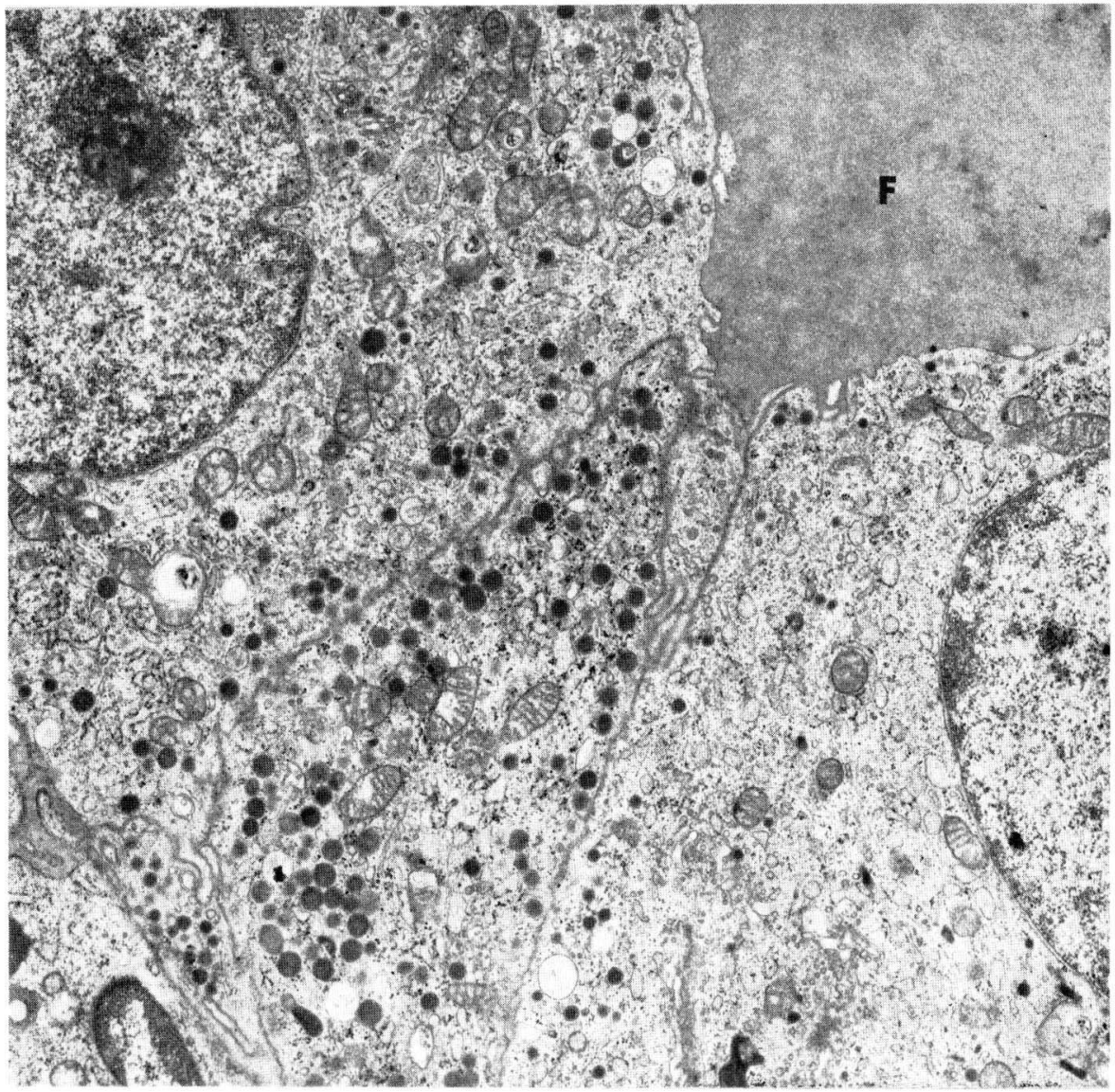

Fig. 5. Microfollicle $(F)$ lined by parafollicular cells. Dense luminal colloids are identical with those of the follicles in the thyroid gland. $\times 11,500$

$>37$ s, and the peak II contained 19s thyroglobulin (thyroglobulin in a strict sense). Anti-peak I antisera absorbed with the peak II fraction showed an immunoreactivity specific to the secretory granules of the parafollicular cells (Fig. 6), while anti-peak II antisera were specific to the follicular cells and colloid droplets (Fig. 7).

Immunoperoxidase staining using the unlabeled antibody-enzyme bridge technique was performed. The sections after rehydration with phosphate buffer saline, PBS (0.15 M sodium chloride in $0.01 \mathrm{M}$ phosphate buffer, $\mathrm{pH} 7.2)$ were applied sequentially with the following solution: appropriate dilutions of the primary antisera to peaks I and II, 30 min; goat anti-rabbit globulin serum (1:10, Medical and Biological Laboratories, Japan), $15 \mathrm{~min}$; rabbit anti-horseradish peroxidase (1: 10, raised in this laboratory against horseradish peroxidase from Sigma), 15 min; horseradish peroxidase (Sigma, type II, $0.5 \mathrm{mg} / 100 \mathrm{ml}$ ) in PBS containing $0.1 \%$ bovine albumin, $15 \mathrm{~min}$; $50 \mathrm{mg} \%$ diaminobenzidine with $0.01 \% \mathrm{H}_{2} \mathrm{O}_{2}$ (0.05 M Tris- $\mathrm{HCl}$ buffer, $\mathrm{pH}$ 7.6), $30 \mathrm{~min}$ to $1 \mathrm{hr}$. Sections were washed in three 7 -minute changes of PBS between application of each solution; all reactions were carried out at room temperature. 


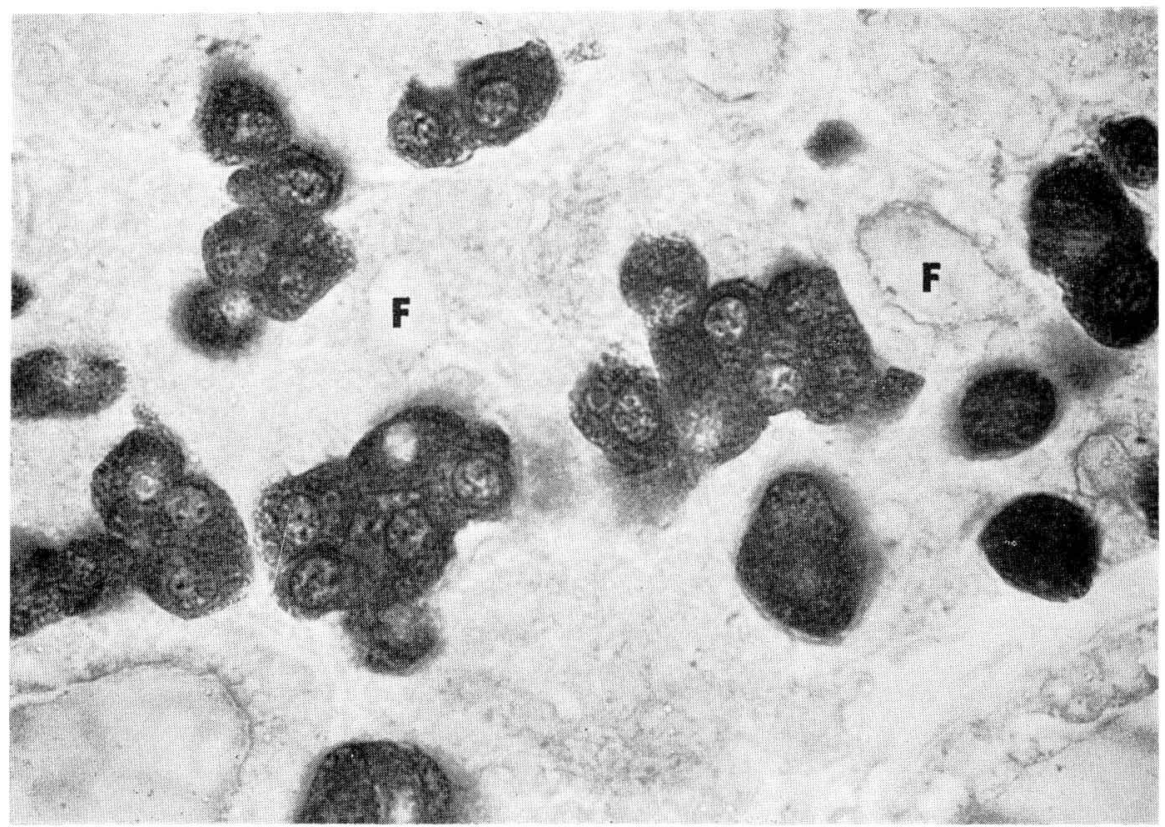

Fig. 6. Dog thyroid gland stained by immunoperoxidase bridge technique using anti-peak I antiserum absorbed with peak II. Only parafollicular cells show a positive reaction. $F$ follicle. $\times 1,000$

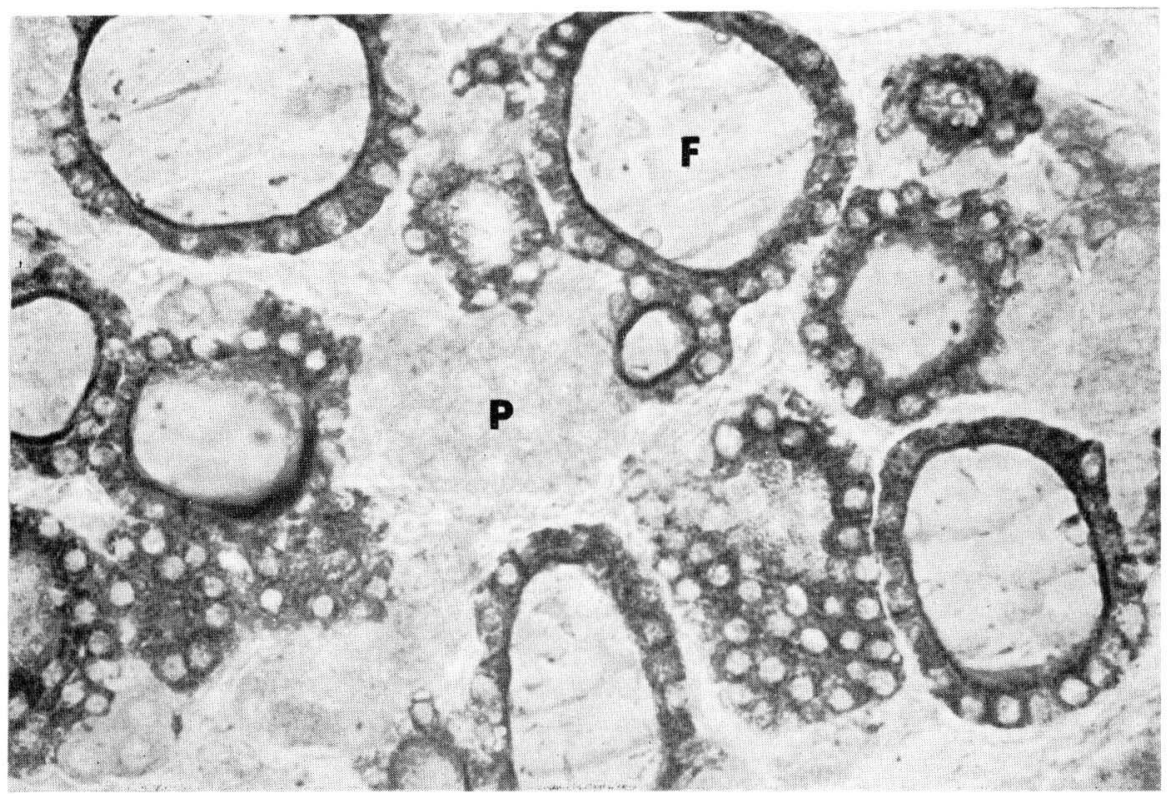

Fig. 7. Dog thyroid gland stained by immunoperoxidase bridge technique using anti-peak II antiserum. Follicular elements (follicular cells and colloid droplets) are heavily stained, while the parafollicular cells $(P)$ are non-reactive. $F$ follicle. $\times 1,000$ 


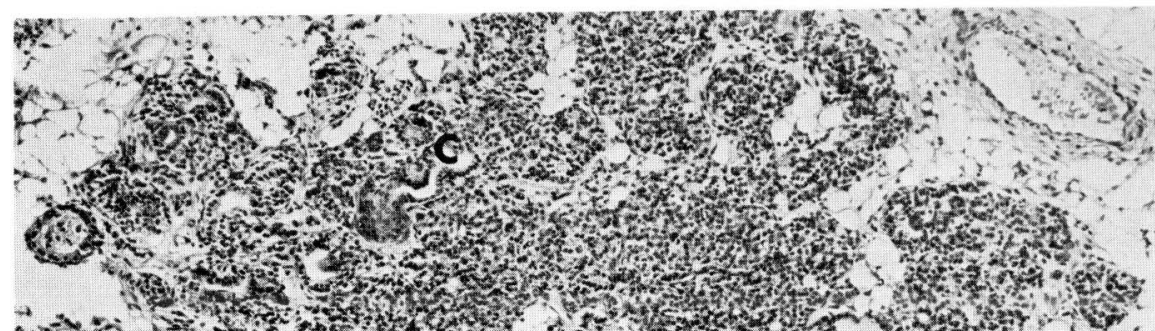
-

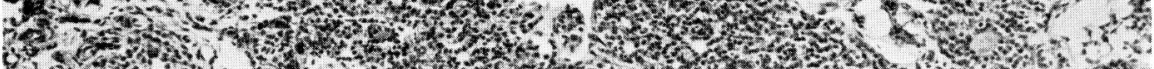

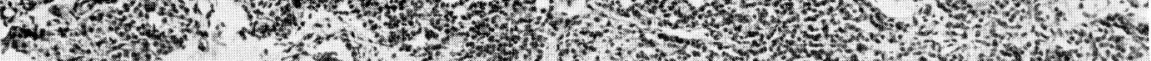

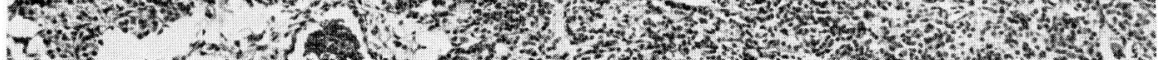
C.

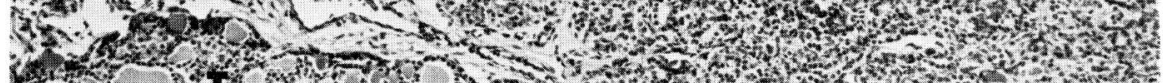

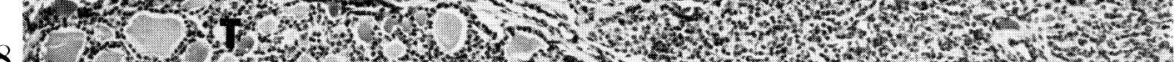

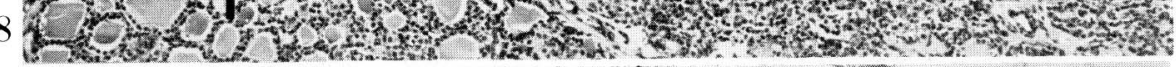

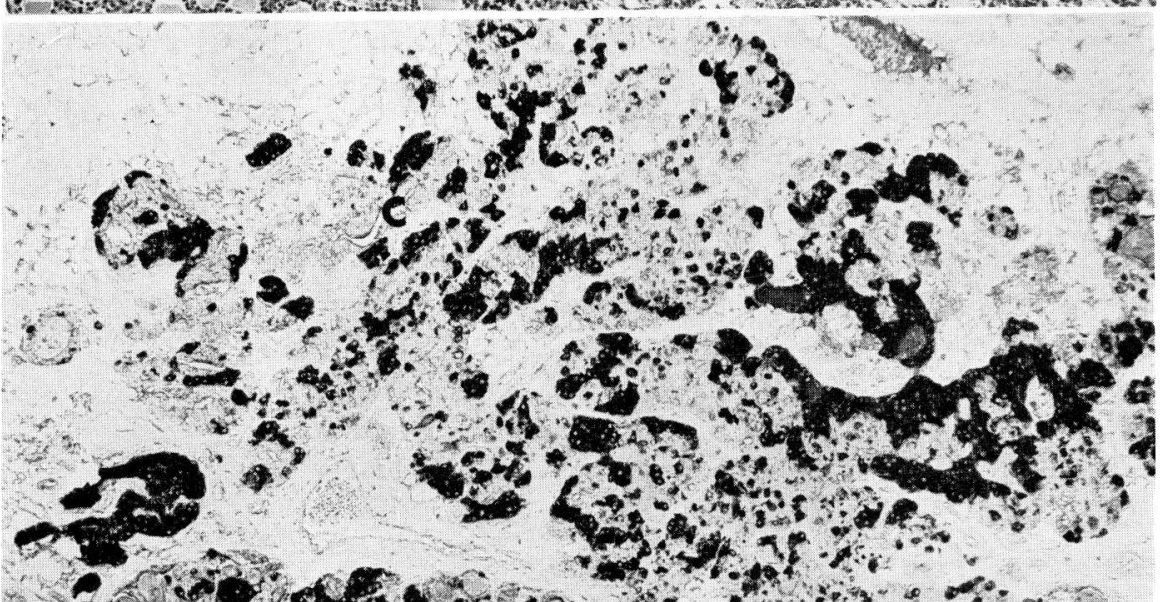

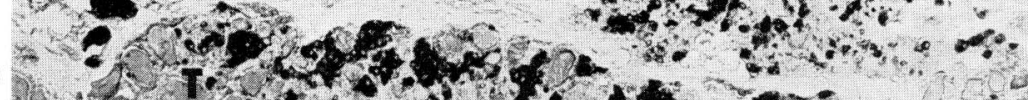

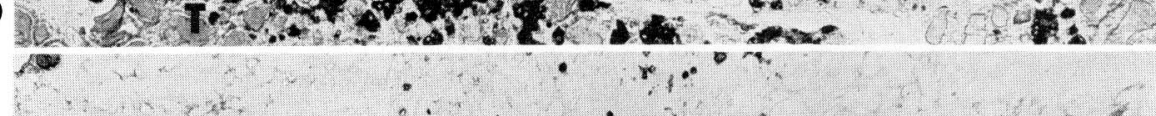

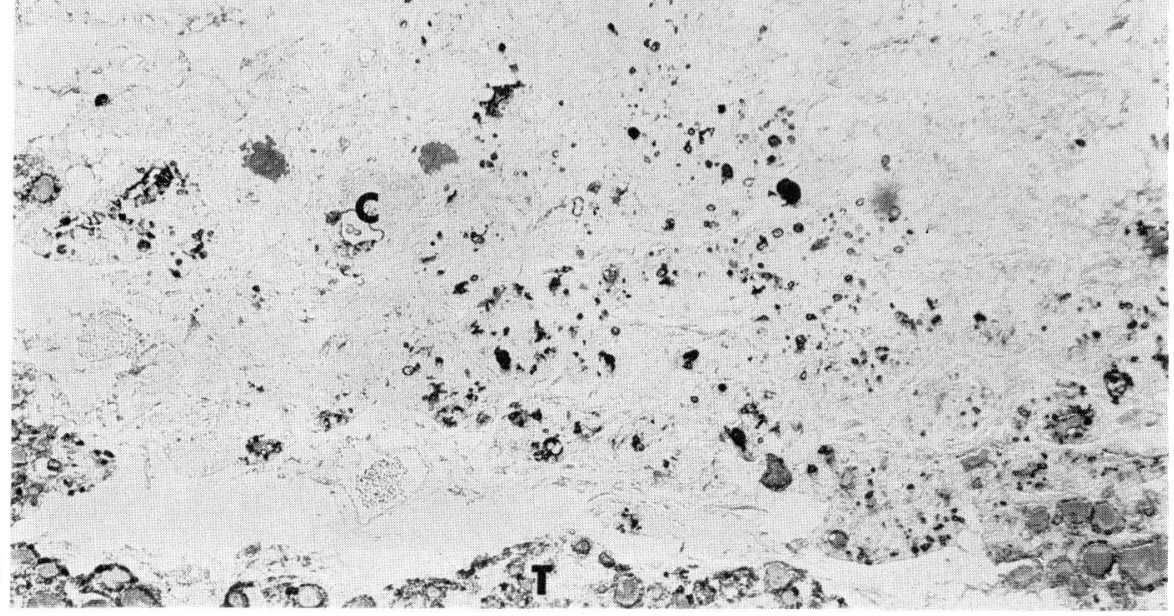

Fig. 8-10. Legend in opposite page. 
By means of the immunoperoxidase method using anti-peak I antisera after absorption with the peak II fraction, the parafollicular cells in the parafollicular cell complex were specifically and intensely stained; they showed a tendency to occur in clusters (Fig. 9). With anti-peak II antisera (anti-19s thyroglobulin antisera), all the follicles in the parafollicular cell complex were stained (Fig. 10, 11). Due to the specificity of the anti-peak II antisera, all the follicular structures were stained; this resulted in an apparent numerical increase when compared with the figures obtained from hematoxylin-eosin stained sections (Fig. 8).

The colloid droplets in the follicular structures in the parafollicular cell complex had considerably stronger antigenicity than those of the thyroid gland. In many follicles in the parafollicular cell complex, dense reaction products were homogenously distributed; while in others, only the peripheral area adjacent to the follicular cells was intensely stained. The staining of the cells lining the follicles differed in inten-

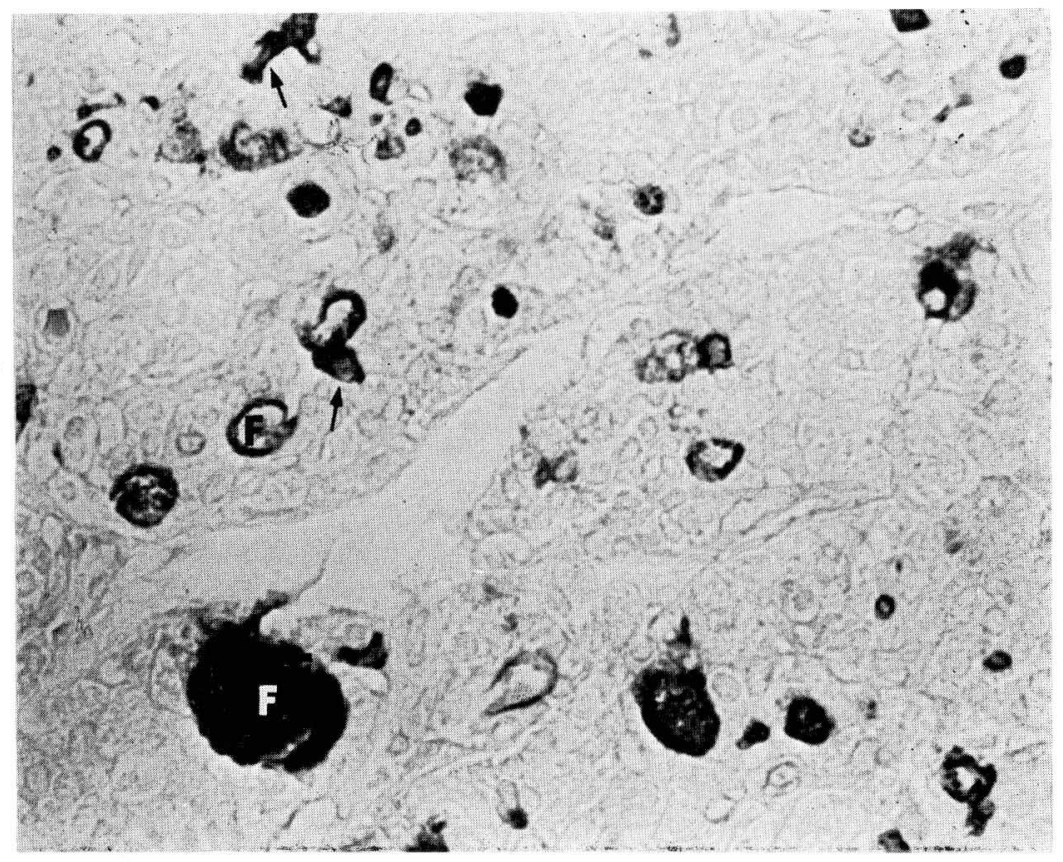

Fig. 11. Higher magnification of a portion of Figure 10. The immunoreactivity to anti-peak II antiserum is different from cell to cell. The follicular cells indicated by the arrows show intense immunoreactivity. $F$ follicle. $\times 600$

Fig. 8-10. Neighboring three serial sections of dog parafollicular cell complex stained by the three kinds of staining methods. $C$ cyst, $T$ thyroid parenchyme. $\quad \times 150$

Fig. 8. Hematoxylin-eosin staining.

Fig. 9. Immunoperoxidase staining using anti-peak I antiserum absorbed with the peak II fraction. The parafollicular cells are filled with dark reaction products.

Fig. 10. Immunoperoxidase staining using anti-peak II antiserum. Numerous microfollicles or minute follicles are demonstrated. Immunoreactivity of the luminal colloids is far stronger than that of the thyroid follicles. 
sity from cell to cell (Fig. 11). The undifferentiated cells were not stained with antipeak I antisera or with anti-peak II antisera.

\section{Origin of the follicular cells in the parafollicular cell complex}

The result of the immunoperoxidase study showed that the colloid-containing follicles within the parafollicular cell complexes store immunoreactive thyroglobulin 19s. Their antigenicity was apparently stronger than that of the thyroid follicles.

It was reported that $17-18$ s thyroglobulin, possessing the same antigenic sites as those of 19s thyroglobulin, was produced in the fetal thyroid gland (OLIN et al., 1970; RoQues et al., 1972). Thus 17-18s thyroglobulin has been regarded as an immature form of thyroglobulin 19s. Therefore, although the follicular cells in the parafollicular cell complex show positive reaction to anti-19s thyroglobulin antisera, the possibility that they produce immature thyroglobulin of a smaller molecular size cannot be excluded.

In their light and electron microscopic observations on the development of the mammalian ultimobranchial body GodwIN, (1937), VAN DyKe (1945) and CALvERT (1972) described that, although most of the follicular cells originate from the median thyroid primordium, a few of them derive from the ultimobranchial body. LoEwNSTEIN and Wollman (1970) described that two populations of thyroid follicles with different radioiodine turnover rates existed and that one population might arise in part from the ultimobranchial body. Thus, it appears probable that the follicular cells in the parafollicular cell complex are of ultimobranchial body origin.

PEARSE (1969) claimed that the high levels of non-specific esterase or cholinesterase are one of the common cytochemical characteristics of the APUD series. GAUGIN and associates (1973) reported that not only parafollicular cells but also some of the follicular cells show a positive cholinesterase reaction. They suggested that the follicular cells might partially derive from the neural crest. However, since cholineesterase reaction is not absolutely specific to the neural crest, it is at present impossible to claim the neural crest origin of the follicular cells.

\section{Origin of the parafollicular cells}

FUJITA (1976) proposed that the common cytochemical and ultrastructural features of the varieties of paraneurons might best be explained by the common neuroectoderm origin of these cells. Thus, if the parafollicular cell is a paraneuron, its precursors should originate from the neuroectoderm.

Electron microscopical investigations on development of the mammalian ultimobranchial bodies have been performed (Ishikawa, 1965; Stoeckel and PoRTe, 1970; CALVERT, 1972; JoRdan et al., 1973). Considerable discrepancies, however, exist concerning the precursors of the parafollicular cells. Furthermore, as mentioned previously, the results of our recent electron microscopical and immunohistochemical study indicated that in the parafollicular cell complex precursor cells of both parafollicular and follicular cells were same in morphological features. That the parafollicular cells may possess the ability to form follicular structures as the follicular cells do, and that parafollicular cells produce a high molecular fragment of thyroglobulin which had been believed to be specific to the follicular cells were also seen (Kameda and Ikeda, 1977a, b).

Presently, the classic view of the endodermal origin of the parafollicular cells 
cannot be conclusively excluded considering their many cytological features held in common with the follicular cells.

Acknowledgment. The author express her sincere thanks to Dr. Takuro Murakami (Department of Anatomy, Okayama University Medical School) for his technical help in the vascular cast preparations.

\section{電顕と免疫組織化学による旁濾胞細胞複合体の研究—一特にパラニューロン としての旁滤胞細胞について}

亀田芙子

哺乳動物において，旁濾胞細胞は甲状腺の中で 滤胞の間に分散しているが，まれにそ れらは上皮小体 $\mathbb{N}$ や胸腺 $\mathbb{N}$ の周辺部で かなり大きな かたまりを形成する．乙れは旁濾胞 細胞複合体と呼ばれ，鰓後体の遺残物と考えられる. 旁濾胞細胞複合体には旁濾胞細胞の 他に甲状腺濾胞細胞と同じ細胞が存在し，コロイドを含む小濾胞を形成する．ここでは， 濾胞細胞と旁濾胞細胞の発生的また機能的関連を調べるために，イヌの旁濾胞細胞複合体 を免疫組織化学および電子顕微鏡によって観察した.

電顕による観察で，旁濾胞細胞複合体には種々の発達段階の濾胞細胞が存在することが わかった，濾胞を形成する以前の細胞は，旁滤胞細胞になるよう運命づけられた細胞と形 態的には区別できない。まれに旁濾胞細胞によって形成されるコロイドを含む小濾胞が観 察された.

抗-19s サイログロブリン抗血清を用い，酵素抗体法で旁濾胞細胞複合体を観察した結 果, 複合体内滤胞は $19 \mathrm{~s}$ サイログロブリンを合成し，それをコロイド滴として蓄えること がわかった．このコロイド滴は，甲状腺内のコロイド滴よりもはるかに強い抗原性を呈 する.

これらの結果にもとづいて, 旁濾胞細胞がパラニューロンである可能性を議論した，パ ラニューロンの仮説では 旁濾胞細胞の神経外胚葉由来が必須であるが, 現段階では内胚葉 由来の考えを捨てさることができない.

\section{References}

Calvert, R.: Electron microscopic observations on the contribution of the ultimobranchial bodies to thyroid histogenesis in the rat. Amer. J. Anat. 133: 269-290 (1972).

Care, A. D. : Significance of the thyroid hormones in calcium homeostasis. Fed. Proc. 27: 153-155 (1968).

Fujita, T.: Gastro-entero-pancreatic endocrine cells and their para-neuronic nature. In: (ed. by) R. E. Coupland and T. Fujita: Chromaffin, enterochromaffin and related cells. Elsevier, Amsterdam, 1976. (p. 191-208). 
Gauguin, J., P. Rømert and S. Kirkeby : Cytochemical demonstration of cholinesterase in follicle cells and parafollicular (C-) cells of the rat thyroid gland. Histochemie 34: 97-106 (1973).

Godwin, M. C. : Complex IV in the dog with special emphasis on the relation of the ultimobranchial body to interfollicular cells in the postnatal thyroid gland. Amer. J. Anat. 60: 299339 (1937).

Ishikawa, K. : Electron microscopical studies of the ultimobranchial body of the rat in embryonic life, with special emphasis on its fate-the relation to the thyroid tissue and parafollicular cells. Fol. anat.d jap. 41: 313-335 (1965).

Jordan, R. K., B. McFarlane and R. J. Scothorne: An electron microscopic study of the histogenesis of the ultimobranchial body and of the C-cell system in the sheep. J. Anat. 114: $115-136$ (1973).

Kameda, Y.: Increased mitotic activity of the parafollicular cells of the dog thyroid in experimentally induced hypercalcemia. Arch. histol. jap. 32: 179-192 (1970).

-: The occurrence of a special parafollicular cell complex in and beside the dog thyroid gland. Arch. histol. jap. 33: 115-132 (1971a).

: The occurrence and distribution of the parafollicular cells in the thyroid, parathyroid IV and thymus IV in some mammals. Arch. histol. jap. 33: 283-299 (1971b).

: Electron microscopic studies on the parafollicular cells and parafollicular cell complexes in the dog. Arch. histol. jap. 36: 89-105 (1973).

: Light and electron microscopic alterations of the dog parafollicular cells induced by antithyroid drug. Arch. histol. jap. 36: 205-220 (1974).

-: Fine structural and endocrinological aspects of thyroid parafollicular cells. In: (ed. by) R. E. Coupland and T. Fujita: Chromaffin, enterochroaffin and related cells. Elsevier, Amsterdam, 1976. (p. 168-170).

Kameda, Y. and A. Ikeda: Occurrence of immunoreactive thyroglobulin in the parafollicular cells of dogs. Experientia 33: 538-540 (1977a).

— : The identification of a specific fragment of dog thyroglobulin responsible for immunoreactivity to the parafollicular cells. Endocrinology (1977b, in press).

Loewenstein, J. E. and S. H. Wollman: Mechanisms for abnormally slow release of some thyroid radioiodine; an autoradiographic study. Endocrinology 87: 143-150 (1970).

Olin, P., R. Ekholm and S. Almqvist : Biosynthesis of thyroglobulin related to the ultrastructure of the human fetal thyroid gland. Endocrinology 87: 1000-1014 (1970).

Pearse, A. G. E. : The cytochemistry and ultrastructure of polypeptide hormone-producing cells of the APUD series and the embryologic, physiologic and pathologic implications of the concept. J. Histochem Cytochem. 17: 303-313 (1969).

Robertson, D. R.: The ultimobranchial body in Rana pipiens III. Sympathetic innervation of the secretory parenchyma. Z. Zellforsch. 78: 328-340 (1967).

Roques, M., J. Torresani, M. Michel-Bechet, A. Jost and S. Lissitzky : Relationship between thyroglobulin synthesis, iodine metabolism, and histogenesis in the developing rabbit fetal thyroid gland. Gen. comp. Endocrinol. 19: 457-472 (1972).

Stoeckel, M. E. and A. Porte : Localisation ultimobranchiale et thyroidienne des cellules C (cellules à calcitonine) chez deux columbidae: le pigeon et le tourtereau. Z. Zellforsch. 102: 376-386 (1969).

: Origine embryonnaire et différenciation sécrétoire des cellules à calcitonine (cellules C) dans la thyroïde foetale du rat. Z. Zellforsch. 106: 251-268 (1970).

Van Dyke, J. H.: Behavior of ultimobranchial tissue in the postnatal thyroid gland: Epithelial cysts, their relation to thyroid parenchyma and to "new-growths" in the thyroid gland of young sheep. Amer. J. Anat. 76: 201-250 (1945).

Watzka, M. : Vergleichende Untersuchungen über den ultimobranchialen Körper. Z. mikrosk.anat. Forsch. 34: 485-533 (1933).

Welsch, U. and Ch. Schubert : Observations on the fine structure, enzyme histochemistry, and 
innervation of parathyroid gland and ultimobranchial body of Chthonerpeton indistinctum (Gymnophiona, Amphibia). Cell Tiss. Res. 164: 105-119 (1975).

亀田芙子

T710-01 倉敷市松島 557

川崎医科大学

解剖学第二講座
Dr. Yoko Kameda

Department of Anatomy

Kawasaki Medical School

Kurashiki, 710-01 Japan 